\title{
A measurement system for vertical seawater profiles close to the air-sea interface
}

\author{
Richard P. Sims ${ }^{1,2}$, Ute Schuster ${ }^{2}$, Andrew J. Watson ${ }^{2}$, Ming Xi Yang $^{1}$, Frances E. Hopkins ${ }^{1}$, John Stephens ${ }^{1}$, and \\ Thomas G. Bell ${ }^{1}$ \\ ${ }^{1}$ Plymouth Marine Laboratory, Plymouth, UK \\ ${ }^{2}$ University of Exeter, Exeter, UK \\ Correspondence to: Thomas G. Bell (tbe@pml.ac.uk)
}

Received: 24 February 2017 - Discussion started: 16 March 2017

Revised: 15 July 2017 - Accepted: 17 July 2017 - Published: 4 September 2017

\begin{abstract}
This paper describes a near-surface ocean profiler, which has been designed to precisely measure vertical gradients in the top $10 \mathrm{~m}$ of the ocean. Variations in the depth of seawater collection are minimized when using the profiler compared to conventional CTD/rosette deployments. The profiler consists of a remotely operated winch mounted on a tethered yet free-floating buoy, which is used to raise and lower a small frame housing sensors and inlet tubing. Seawater at the inlet depth is pumped back to the ship for analysis. The profiler can be used to make continuous vertical profiles or to target a series of discrete depths. The profiler has been successfully deployed during wind speeds up to $10 \mathrm{~m} \mathrm{~s}^{-1}$ and significant wave heights up to $2 \mathrm{~m}$. We demonstrate the potential of the profiler by presenting measured vertical profiles of the trace gases carbon dioxide and dimethylsulfide. Trace gas measurements use an efficient microporous membrane equilibrator to minimize the system response time. The example profiles show vertical gradients in the upper $5 \mathrm{~m}$ for temperature, carbon dioxide and dimethylsulfide of $0.15^{\circ} \mathrm{C}$, $4 \mu \mathrm{atm}$ and $0.4 \mathrm{nM}$ respectively.
\end{abstract}

\section{Introduction}

Exchange between the ocean and atmosphere is an important process for many gases. Important examples include carbon dioxide $\left(\mathrm{CO}_{2}\right)$, for which the oceans account for $25 \%$ of the sink for anthropogenic emissions (Le Quéré et al., 2016), and dimethylsulfide (DMS), which has an oceanic source and influences cloud properties with implications for the global energy balance (Quinn and Bates, 2011). The magnitude and direction of air-sea gas transfer is typically represented by Flux $=K \Delta \mathrm{C}$ (Liss and Slater, 1974), where $\Delta \mathrm{C}$ is the concentration difference across the air-sea interface and $K$ is the gas transfer velocity. Direct flux measurements (Bell et al., 2013; Yang et al., 2013; Miller et al., 2010) are only possible for a small number of gases and are not made routinely. Most flux estimates use a wind-speed-based parameterization of $K$ (e.g. Wanninkhof, 2014) coupled with measurements of $\Delta C$.

$\mathrm{CO}_{2}$ is the most well-observed trace gas in the surface ocean, with 14.5 million measurements compiled into a global database, the Surface Ocean $\mathrm{CO}_{2}$ Atlas (SOCAT), http://www.socat.info/ (Bakker et al., 2016). Global trace gas databases also exist for gases such as methane and nitrous oxide https://memento.geomar.de/ (Bange et al., 2009), dimethylsulfide http://saga.pmel.noaa.gov/dms/ (Lana et al., 2011) and halocarbons https://halocat.geomar.de/ (Ziska et al., 2013). Accurate estimation of air-sea flux requires concentration measurements that are representative of the interfacial concentration difference. Surface seawater samples are often collected from the underway seawater intake of research vessels, typically at 5-7 $\mathrm{m}$ depth. A source of potential error in air-sea flux calculations arises from the assumption of vertical homogeneity within the mixed layer (Robertson and Watson, 1992). If vertical concentration gradients exist in the mixed layer, then underway seawater is not representative of the interfacial layer, which could create a global sampling bias (McNeil and Merlivat, 1996).

Vertical gradients in trace gas concentrations have been observed under conditions that are favourable for nearsurface stratification (Royer et al., 2016). At low wind speeds, high solar irradiance can suppress the depth of shear- 
induced mixing to create a near-surface layer several degrees warmer than the water below (Ward et al., 2004; Fairall et al., 1996). Near-surface stratification in the marine environment can also be induced by freshwater inputs such as rain (Turk et al., 2010) and riverine discharge. Changes in surface seawater temperature and salinity alter the solubility of dissolved gases and thus the amount available for air-sea exchange (Woolf et al., 2016). Dissolved gases isolated in the upper few metres of the ocean may additionally be modified by physical processes such as air-sea exchange and photochemistry. Marine biota confined within the stratified layer (Durham et al., 2009) can also alter trace gas concentrations. For the purposes of this paper, near-surface gradients are defined as physical and/or chemical gradients in the upper $10 \mathrm{~m}$ of the ocean.

Identifying and quantifying near-surface gradients in trace gas concentrations is challenging. Ship motion often inhibits near-surface measurements made with the standard oceanographic approach of sampling with Niskin bottles mounted on a CTD rosette. Substantial vertical movement of the rosette limits how close to the surface a sample can be taken. For example, a crane arm $4 \mathrm{~m}$ above the sea surface and $11 \mathrm{~m}$ from the centreline of a ship that is rolling by $\pm 4^{\circ}$ will induce $\sim 1.5 \mathrm{~m}$ sample depth variation every few seconds. CTD/Niskin bottle sampling requires that the rosette is kept below the sea surface. Sampling within $2 \mathrm{~m}$ of the sea surface is often impossible, even under relatively calm conditions.

We present a near-surface ocean profiling buoy (NSOP) designed for measuring near-surface profiles. The design principles for NSOP were as follows:

1. platform diameter less than the wavelength of most open ocean waves, allowing it to ride the swell;

2. short sampling arm close to the sea surface to reduce vertical movements induced by platform motion;

3. capable of deployment close to the ship (to retrieve water for trace gas analysis), but away from major turbulence and motion due to the ship itself.

Example profiles from a cruise on the European continental shelf (RRS Discovery, DY033, July 2015) and in the English Channel on board the RV Plymouth Quest (part of the Western Channel Observatory; Smyth et al. 2010, April 2014) are discussed.

\section{Methods}

\subsection{NSOP description}

NSOP is a repurposed ocean buoy (1.6 m diameter) with a central lifting eyelet (Fig. 1). The top of the buoy is $0.5 \mathrm{~m}$ above the sea surface. Mounted on top of the buoy are a line of sight, remotely operated winch (Warrior Winch, model C8000) and a gel battery (Haze, model HZY-S112-230). The winch feeds Kevlar rope through a block and tackle with a $3: 1$ ratio to reduce rope pay-out speed to $\sim 0.05 \mathrm{~m} \mathrm{~s}^{-1}$. The block and tackle is attached to the end of an outstretched arm $0.25 \mathrm{~m}$ from the outer edge of the buoy. The winch line is attached to an open frame $(0.35 \mathrm{~m}$ diameter, $0.8 \mathrm{~m}$ height $)$ with the capacity to house multiple sensors. Desired sampling depth is targeted using knowledge of the winch payout speed. Rope pay-out is then timed with a stopwatch. This approach only approximately regulates the sampling depth because (i) winch pay-out varies slightly depending on the amount of rope on the spool and (ii) variable horizontal current strength affects the vertical versus horizontal position of the sampling frame. To minimize horizontal movement of the sampling frame we attached a $10 \mathrm{~kg}$ weight to the base of the frame.

The primary sensor on the sampling frame is a small CTD (Valeport miniCTD) set to sample at a high frequency $(>1 \mathrm{~Hz})$. Under calm conditions it is possible to sample as close as $0.1 \mathrm{~m}$ from the air-sea interface when the miniCTD and tubing are mounted near the top of the frame. Rougher conditions demand that the frame be kept deeper $(\sim 0.5 \mathrm{~m})$ as motion can momentarily bring the sensors and tubing out of the water. An emergency tag line was attached to the sampling frame in case the winch line failed. Seawater for trace gas analysis was pumped back to the ship at $3.5 \mathrm{~L} \mathrm{~min}^{-1}$ through a $50 \mathrm{~m}$ PVC hose $(0.5$ in inner diameter). A heavy-duty peristaltic pump (Watson Marlow, model 701IB/R) primed with water from the ship's underway supply was used to overcome the large hydraulic head $(\sim 4 \mathrm{~m})$. The open end of the tubing was located at the same depth as the miniCTD. Water arriving to the ship's laboratory was divided, with $\sim 3.0 \mathrm{~L} \mathrm{~min}^{-1}$ for flow-through analysis (e.g. equilibrator for trace gases) and $\sim 0.5 \mathrm{~L} \mathrm{~min}^{-1}$ for discrete samples (e.g. total alkalinity).

We assessed the depth resolution capability of NSOP at a particular depth by looking at pressure variations under calm conditions with a fixed amount of winch rope paid out. In calm to moderate conditions $(<2.5 \mathrm{~m}$ significant wave height) the amount of vertical movement indicated by the standard deviation (SD) in the depth is $\pm 0.18 \mathrm{~m}$ (Fig. S1, Supplement). During four deployments in rough conditions ( $>2.5 \mathrm{~m}$ significant wave height), the depth variability increased as the sampling frame was lowered (at $5 \mathrm{~m}$, SD was $\pm 0.275 \mathrm{~m})$.

\subsection{NSOP deployment}

On a large research vessel such as the RRS Discovery, the deployment and recovery of NSOP requires close coordination between the bridge and three personnel on deck. The NSOP was always deployed while the ship was on station and not at the same time as other overboard deployments. Ship orientation during deployments was typically with bow into the wind but also accounted for swell and current direction/speed. The NSOP was lifted by the aft crane (Fig. 1). 
Once the NSOP had been lowered to the surface it was detached from the crane via a quick release. Two slack lines were looped through eyelets on the free-floating NSOP to maintain its position close to the ship. A third slack line was connected to the top of the buoy and passed through a block on a fully extended crane arm of $7 \mathrm{~m}$ to maintain this distance between NSOP and the ship. The slack lines successfully inhibited the tendency of NSOP to drift horizontally without disrupting its ability to ride the swell. The instrument frame acted like a sea anchor and minimized rotation of NSOP. A $4 \mathrm{~m}$ lifting strop used for recovery was connected to the lifting eyelet and loosely lashed to the aft slack line. During retrieval, the slack lines were hauled in and the crane and jib arms brought towards the ship to bring NSOP alongside. The lifting strop was then parted from the slack line and attached to the crane to lift NSOP back on deck. For additional photographs of a NSOP deployment and videos of NSOP during a deployment and in operation see Fig. S2 and videos.

Turbulence from the ship's propellers has the potential to mix the water column and destroy any near-surface gradients. The ship did not use the aft thrusters whenever conditions were suitable (mild sea state, weak currents and no local hazards). Keeping the NSOP away from the ship limited disruption of near-surface gradients by the thrusters and reduced the risk of line entanglement in the aft propellers. Our winch did not have a groove bar to feed the rope onto the winch drum, leading to an increased likelihood of snagging during spooling. To minimize snagging, the rope was manually fed onto the winch spool before deployments. Visual monitoring of the NSOP frame, slack lines and winch spool is important during deployment.

The NSOP has been successfully deployed in "moderate" sea states up to Beaufort force $5\left(\sim 10 \mathrm{~m} \mathrm{~s}^{-1}\right.$ wind speed and wave heights of $\sim 2.0 \mathrm{~m})$. Deployment length typically varied from 1 to $3 \mathrm{~h}$.

The NSOP can be used in two profiling modes: "continuous" and "discrete". Continuous profiling maximizes vertical coverage and involves the winch continuously paying rope in and out at $\sim 0.05 \mathrm{~m} \mathrm{~s}^{-1}$. A complete down/up profile to $10 \mathrm{~m}$ can be conducted in approximately $7 \mathrm{~min}$. Depth resolution during continuous profiling is determined by the measurement response time. Instruments with rapid response times such as the miniCTD temperature and conductivity sensors $(0.15$ and $0.09 \mathrm{~s})$ have theoretical depth resolutions of 0.75 and $0.45 \mathrm{~cm}$ respectively. Actual depth resolution will also be affected by the sampling depth variability of the NSOP instrument frame. A measurement setup with a longer response time (such as for seawater $\mathrm{CO}_{2}$ ) requires a different approach (see Sect. 2.5).

During discrete profiling, the winch pays out a fixed amount of rope (typically $0.5 \mathrm{~m}$ ) and the sampling frame is left at a fixed depth. After a fixed sampling period, more rope is paid out. The process is repeated down and then up such that a set of discrete depths are sampled in a "stepped" profile. The discrete profiling depth resolution is determined by

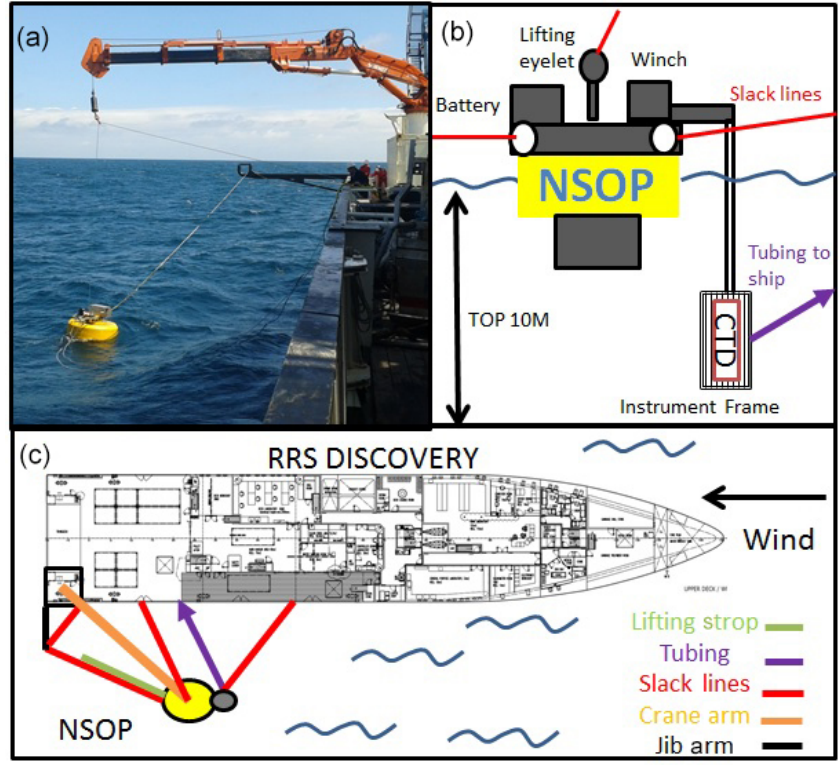

Figure 1. Different points of view of an NSOP deployment: (a) image from a deployment on RRS Discovery in May 2015 (Cruise DY030), (b) schematic cross section of NSOP including tubing back to ship (purple) and slack lines (red), and (c) top-down schematic from a research ship including ship orientation. Not to scale.

the depth fluctuations when sampling at a fixed depth (see Sect. 2.1). Discrete profiles are a more appropriate approach for measurement systems with a longer response time. A discrete profile with $0.5 \mathrm{~m}$ steps down to $5 \mathrm{~m}$ and back to the surface using a 2.5 min sampling period takes about an hour. The sampling period at each depth and frequency/distribution of depths within the profile can be adjusted to suit sampling priorities.

The maximum deployment time is limited by the capacity of the winch battery. When under no load, the battery allows for approximately $3 \mathrm{~h}$ of operation in the continuous mode. Discrete profiling requires substantially less winch usage such that battery drainage is even less of a concern.

\section{$2.3 \mathrm{CO}_{2}$ analysis}

The $\mathrm{CO}_{2}$ measurement system (Fig. 2) is a modified version of the system described by Hales et al. (2004). Seawater from the NSOP inlet was passed through the equilibrator (see Sect. 2.3.1) at $\sim 3 \mathrm{~L} \mathrm{~min}^{-1}$ and the flow rate monitored (Cynergy ultrasonic flow meter, model UF25B). A compressed nitrogen gas supply, maintained at a constant flow rate of $100 \mathrm{~mL} \mathrm{~min}^{-1}$ (Bronkhurst mass flow controller, model F-201-CV-100) flows through the equilibrator in the opposite direction to the seawater flow. The gas has high water vapour content after equilibration and is dried (Permapure nafion dryer, model MD-110-48S-4). The dried sample then 


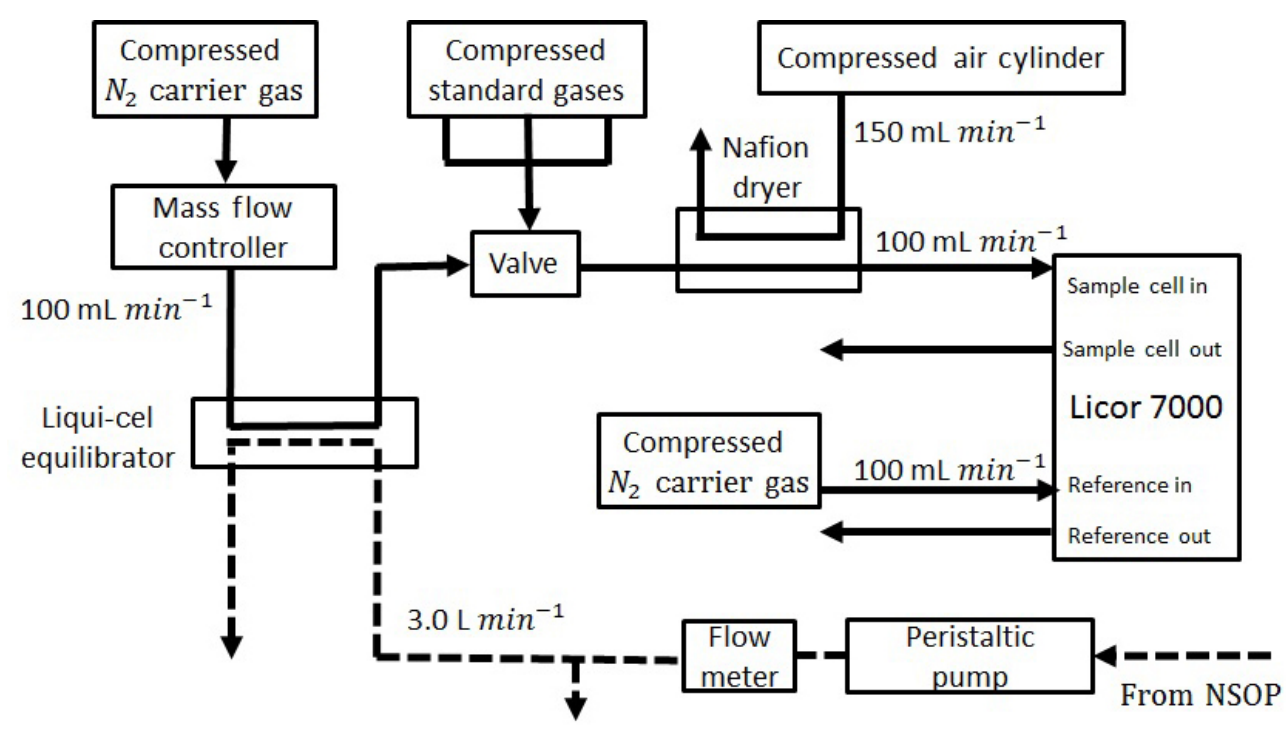

Figure 2. $\mathrm{CO}_{2}$ system schematic. Solid and dashed arrows correspond to gas and water flows respectively. The LI-COR reference cell is flushed with equilibrated gas at $100 \mathrm{~mL} \mathrm{~min}^{-1}$. A manual selection valve was used to switch between equilibrated gas and the $\mathrm{CO}_{2}$ standards.

enters the analytical cell of a NDIR LI-COR 7000, which is protected with a $0.2 \mu \mathrm{m}$ filter (Pall, Acro 50).

$\mathrm{CO}_{2}$ measurements at atmospheric pressure as recommended by Dickson et al. (2007) were not possible due to the nature of the experimental setup. The continuous gas flow through the system caused a small $0.4 \mathrm{kPa}$ pressure increase in the LI-COR measurement cell; this was in good agreement with a similar observation by B. Hales $(0.5 \mathrm{kpa}>$ ambient pressure; personal communication, 2014). The elevated pressure was taken to be representative of the equilibrator pressure and was used to obtain the partial pressure of $\mathrm{CO}_{2}$ in the equilibrator $\left(p \mathrm{CO}_{2(\mathrm{eq})}\right)$.

The LI-COR was calibrated using three $\mathrm{CO}_{2}$ standard gases before and after each NSOP deployment. The concentrations of the standard gases (BOC Ltd) were determined by referencing against US National Oceanic and Atmospheric Administration certified standards (244.91, 388.62, $444.40 \mathrm{ppm}$ ) in the laboratory. The seawater temperature at the entry and exit ports of the equilibrator was recorded at $1 \mathrm{~Hz}$ (Omega ultra-precise 1/10 DIN immersion RTD) using stackable microcontrollers (Tinkerforge master brick 2.1 and PTC bricklet). Equilibrator temperature probes and the miniCTD temperature sensor were calibrated before and after each cruise against an accurate reference sensor (Fluke, model $5616-12, \pm 0.011^{\circ} \mathrm{C}$ ) in a stable water bath (Fluke 7321).

\section{Equilibrator}

The showerhead equilibrator is the most commonly used equilibrator for $\mathrm{CO}_{2}$ but takes $\sim 100$ s to equilibrate (Dickson et al., 2007; Kitidis et al., 2012; Körtzinger et al., 2000; Webb et al., 2016). This equilibration time is too slow for ef- fective use during NSOP deployments. We used a polypropylene membrane equilibrator (Liqui-Cel, model $2.5 \times 8$ ) with liquid and gas volumes of 0.4 and $0.15 \mathrm{~L}$ and a surface area of $1.4 \mathrm{~m}^{2}$. Due to its large surface area to volume ratio and membrane porosity (50\%), the Liqui-Cel expedites gas transfer and efficiently achieves equilibration (Loose et al., 2009), with a $3 \mathrm{~s}$ response time for $\mathrm{CO}_{2}$ (Hales et al., 2004). Membrane equilibrators have been used by others for trace gas analysis (Hales et al., 2004; Marandino et al., 2009).

Fugacity of seawater $\mathrm{CO}_{2}$ is calculated from the LI-COR gas phase $\mathrm{CO}_{2}$ measurement. This approach assumes that the gas phase sample has equilibrated fully with the seawater. We performed equilibration efficiency experiments in a seawater tank using a showerhead equilibrator as a reference. LiquiCel equilibration efficiency declined after prolonged exposure to seawater, likely due to biofouling of the membranes. In a fouled equilibrator, equilibration efficiency was a function of the flow rate on both the water and gas side of the membrane. An increased gas flow rate reduces the residence time inside the Liqui-Cel and allows less time to equilibrate (Fig. 3a). Increasing the waterside flow rate moves the gas phase closer to equilibrium because the transfer coefficient in the membrane increases (Fig. 3b).

Cleaning with an acid-base sequence restored the efficiency of a fouled equilibrator. It was necessary to actively pump chemicals through the Liqui-Cel to achieve a full recovery in efficiency. For more details on cleaning techniques, see Supplement. Efficiency reductions in membrane equilibrators like the Liqui-Cel have not been reported by previous studies. Some authors have used 5-50 $\mu \mathrm{m}$ filters to minimize biofouling (Hales et al., 2004) but this was not possible with the NSOP experimental design. If filtering seawater is not possible, we recommend flushing with freshwater after use, 

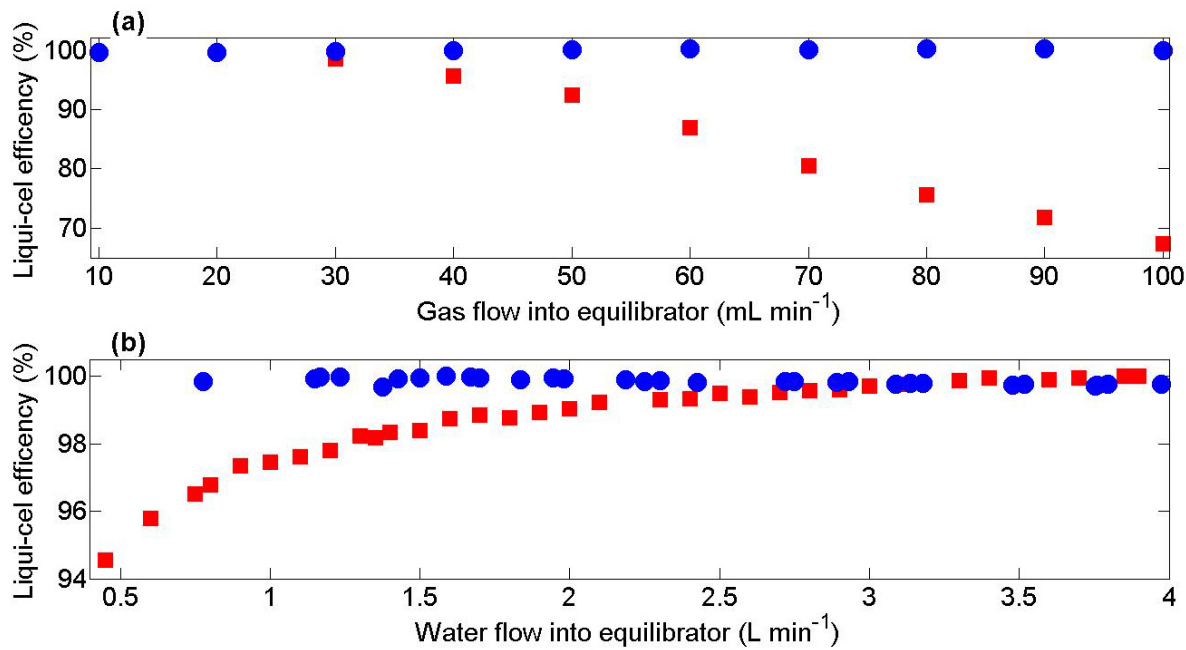

Figure 3. Liqui-Cel $\mathrm{CO}_{2}$ equilibration efficiency (Liqui-Cel mixing ratio/showerhead mixing ratio) for (a) changing gas flow at a fixed water flow rate of $4 \mathrm{~L} \mathrm{~min}^{-1}$ and (b) changing water flow at a fixed gas flow of $100 \mathrm{~mL} \mathrm{~min}^{-1}$. Blue: unfouled equilibrator. Red: fouled equilibrator.

regular cleaning of the Liqui-Cel and daily tests to quantify equilibration efficiency. Trace gas measurement systems that use an internal liquid phase standard (e.g. dimethylsulfide, Sect. 2.4) account for any changes in equilibrator efficiency.

\subsection{DMS analysis}

DMS was measured with atmospheric pressure chemical ionization mass spectrometry (API-CIMS), using a system modified following Saltzman et al. (2009). Measurements were calibrated using an isotopic liquid standard of tri-deuterated DMS (see Bell et al., 2013 for details). Isotopic standard was injected at $120 \mu \mathrm{L} \mathrm{min}^{-1}$ into the $3 \mathrm{~L} \mathrm{~min}^{-1}$ seawater flow from NSOP before it entered the Liqui-Cel equilibrator. Compressed nitrogen gas was passed through the equilibrator in the counter direction to the seawater flow at $1 \mathrm{~L} \mathrm{~min}^{-1}$. The use of an internal standard meant that any incomplete equilibration of the ambient non-isotopic DMS was also true for the isotope. The gas stream exited the equilibrator and was dried (Permapure nafion dryer, model MD-110-48S-4) before entering the mass spectrometer for analysis. DMS was detected at $\mathrm{m} / z$ (mass/charge) 63 and the isotopic standard detected at $m / z$ 66. The concentration of DMS was calculated using the ion signals and relevant flow rates (Bell et al., 2015). This approach has been shown to compare well with other analytical techniques for DMS (Royer et al., 2014; Walker et al., 2016).

\subsection{NSOP delay and response time}

We used different approaches to assess the delay between instantaneous miniCTD measurements and water arriving to the ship for analysis. The delay between seawater entering the inlet and reaching the equilibrator was calculated as $114 \mathrm{~s}$ using the internal volume of NSOP tubing $(0.5$ in inner diam- eter, $54 \mathrm{~m}$ length) and a seawater flow rate of $4.15 \mathrm{~L} \mathrm{~min}^{-1}$. Delay correlation analysis between the NSOP miniCTD temperature sensor and a second sensor positioned at the entrance to the equilibrator gives a similar delay of $112 \mathrm{~s}$. Note that the total delay of the system is greater because it also includes the time that equilibrated gas takes to reach the LICOR. We determined the total delay by transferring the seawater inlet quickly between two buckets with distinctly different $\mathrm{CO}_{2}$ concentrations and timing how long it took for the signal to be detected by the LI-COR (139 s; Fig. 4).

The response time of the NSOP setup was determined by simulating step changes in gas concentrations. A model fit to the exponential change in signal was used to estimate the response time (Fig. 4). We estimate the system response time ( $e$-folding time) for $\mathrm{CO}_{2}$ as $24 \mathrm{~s}$, which is slightly faster than the $34 \mathrm{~s}$ reported by Webb et al. (2016). The $e$-folding time in the DMS signal is estimated as $11 \mathrm{~s}$, which is consistent with the rapid gas flow rate through the analytical system.

Continuous profiling with the $\mathrm{CO}_{2}$ system and a $24 \mathrm{~s}$ response time yields a depth resolution of $1.2 \mathrm{~m}$, which is greater than the required resolution to assess near-surface gradients. DMS has a faster response time than $\mathrm{CO}_{2}$, but in continuous profiling mode this only translates to a depth resolution of $0.6 \mathrm{~m}$, slightly less than the $1.2-2 \mathrm{~m}$ reported by Royer et al. (2014). A depth resolution of $<0.5 \mathrm{~m}$ was desired to capture upper ocean vertical gradients in $\mathrm{CO}_{2}$ and DMS so NSOP was operated in discrete profiling mode.

\subsection{Data processing}

During discrete profiling, distinct sample depths were identified from the rapid changes in pressure during depth transitions. Data were binned into discrete depth bins using CTD pressure measurements. Trace gas data were assigned to depth bins after adjusting for the calculated transit time 


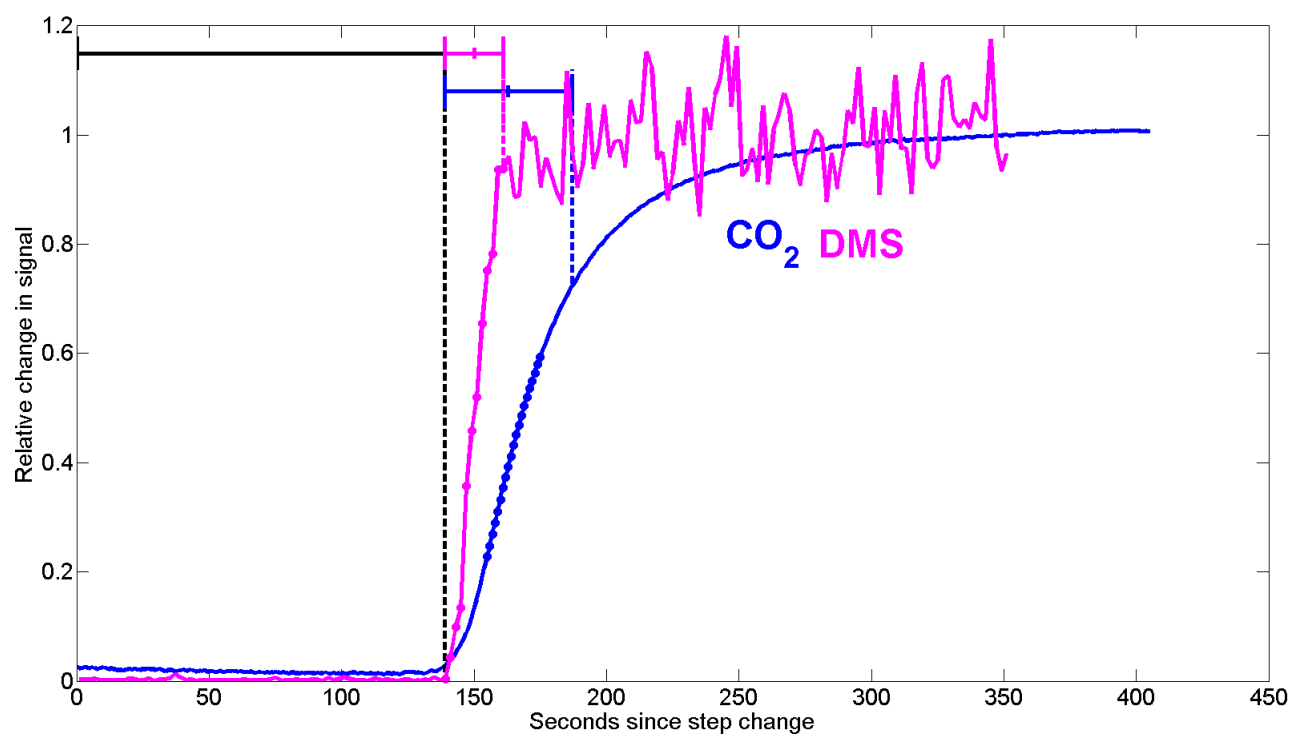

Figure 4. Instrument responses to step changes in seawater $\mathrm{CO}_{2}$ (blue) and DMS (magenta). Step changes from 350 to $400 \mu$ atm for $\mathrm{CO}_{2}$ and 0 to $2 \mathrm{nmol} \mathrm{L}^{-1}$ for DMS have been scaled down so that the initial and end concentrations are between 0 and 1 . Time is referenced against the point when the step change was initiated. The response is seen in both instruments after a delay of $138 \mathrm{~s}$ (black dashed line). Two $e$-foldings are indicated by vertical dashed lines for $\mathrm{CO}_{2}$ (blue) and DMS (magenta). The data points marked by circles were used to make an exponential fit to the data to determine the response time (Sect. 2.5).

through the NSOP tubing (Sect. 2.5). $\mathrm{CO}_{2}$ data from the beginning ( $2 e$-foldings $+15 \mathrm{~s}$ buffer $=63 \mathrm{~s})$ and end $(15 \mathrm{~s}$ buffer) of each depth bin was excluded from analysis to account for the response time of the system and the transition time between sample depths. The same approach was taken for DMS, where the faster response time resulted in a smaller portion of data excluded at the beginning of each depth bin ( $2 e$-foldings $+15 \mathrm{~s}$ buffer $=37 \mathrm{~s})$.

The $\mathrm{CO}_{2}$ mixing ratio $\left(\mathrm{xCO}_{2}\right)$ measured in the LI-COR is converted to equilibrator fugacity $\left(f \mathrm{CO}_{2(\mathrm{eq})}\right)$ using calibration standards, in situ seawater salinity, and the pressure and temperature in the equilibrator (SOP 5\# Underway $p \mathrm{CO}_{2}$; Dickson et al., 2007). Vertical profiles of seawater $\mathrm{CO}_{2} \mathrm{fu}-$ gacity $\left(f \mathrm{CO}_{2(\mathrm{sw})}\right)$ are calculated using average equilibrator fugacity $\left(f \mathrm{CO}_{2(\mathrm{eq})}\right)$, equilibrator temperature $\left(T_{(\mathrm{eq})}\right)$ and in situ seawater temperature $\left(T_{(\mathrm{sw})}\right)$ at each depth (Takahashi et al., 1993).

\subsection{Seawater sample collection using NSOP}

The NSOP setup enables vertical profiles of discrete seawater samples to be collected from upstream of the equilibrator, with a split in the tubing diverting $\sim 0.5 \mathrm{~L} \mathrm{~min}^{-1}$ into a sink. For example, discrete seawater samples $(250 \mathrm{ml})$ have been successfully collected and analysed for Total Alkalinity (TA). Samples were collected and poisoned following best practice recommendations (SOP\#1; Dickson et al., 2007). Bottle filling plus one overfill took $\sim 60 \mathrm{~s}$. Start and end times were recorded so that collection depth could be retrospectively de- termined from the CTD pressure data. Analytical methods and an example depth profile are provided in the Supplement.

\section{Field measurements/observations}

Presented below are example profiles collected using NSOP. The first deployment was in the open ocean (30 July 2015, central Celtic Sea; $49.4213^{\circ} \mathrm{N},-8.5783^{\circ} \mathrm{E}$ ) from the RRS Discovery (100 m length, $6.5 \mathrm{~m}$ draught). The second deployment was in coastal waters (15 April 2014, Plymouth Sound; $\left.50.348^{\circ} \mathrm{N},-4.126^{\circ} \mathrm{E}\right)$ from the RV Plymouth Quest $(20 \mathrm{~m}$ length, $3 \mathrm{~m}$ draught). A map of deployment sites is supplied in the Supplement.

\subsection{Open-ocean deployment}

NSOP was deployed at 14:05 (UTC) on 30 July 2015. During the $6 \mathrm{~h}$ preceding deployment, the ship was on station and encountered persistently strong solar radiance $\left(>600 \mathrm{~W} \mathrm{~m}^{-2}\right)$, mild winds $\left(<6 \mathrm{~m} \mathrm{~s}^{-1}\right)$ and calm sea state (significant wave height $<1.6 \mathrm{~m}$ ). This combination of low wind speeds and high irradiance (Fig. S5) is favourable for near-surface stratification (Donlon et al., 2002).

Figure 5 presents the time series data collected by NSOP for depth, temperature, salinity and $f \mathrm{CO}_{2(\mathrm{sw})}$. Discrete profiling began at 14:05 (UTC) at $0.7 \mathrm{~m}$ depth, which was as close to the surface as the frame could be located without the possibility of breaking the surface. Depth bins were identified based on rapid depth transitions (Fig. 5a). Bottles were filled for discrete samples during the downcast. 

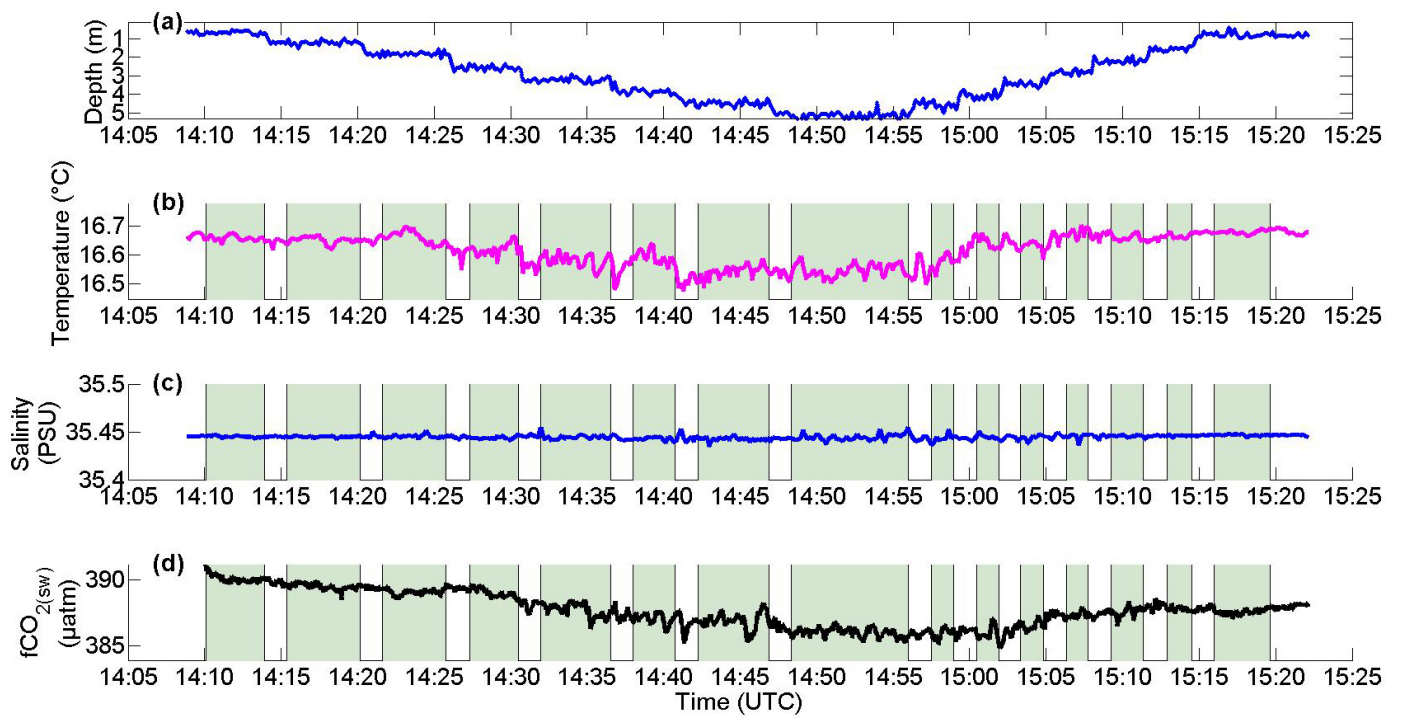

Figure 5. Time series measurements made during an NSOP deployment in the Celtic Sea on 30 July 2015. Data are $1 \mathrm{~Hz}$ depth (a), seawater temperature (b), salinity (c) and $f \mathrm{CO}_{2(\mathrm{sw})}$ (d). Data used for depth bin analysis (Sect. 2.6) are identified by a shaded background.

Profiling lasted $75 \mathrm{~min}$ and finished back at the surface at 15:20 (UTC). Seawater temperature was $16.61 \pm 0.06^{\circ} \mathrm{C}$. At 14:20 (UTC), $f \mathrm{CO}_{2(\mathrm{~atm})}$ was $398 \mu \mathrm{atm}$ and $f \mathrm{CO}_{2(\mathrm{sw})}$ was $389 \mu$ atm at $0.67 \mathrm{~m}$, meaning the ocean was undersaturated with respect to the atmosphere. The temperature and seawater $\mathrm{CO}_{2}$ were the expected magnitude for summer in the Celtic Sea (Frankignoulle and Borges, 2001). Salinity was homogeneous throughout the NSOP deployment, only varying by \pm 0.004 .

Depth-binned salinity and temperature data did not show any significant variability (Fig. 6a). A slight temperature gradient was observed, with $0.15^{\circ} \mathrm{C}$ difference between $5 \mathrm{~m}$ and the surface and a fairly constant reduction with depth $\left(0.03{ }^{\circ} \mathrm{C}\right.$ per metre $)$. The temperature profile was similar for down- and upcasts, although some continued warming of surface waters was evident in the upcast. The temperature measured by NSOP at $5.15 \mathrm{~m}$ depth agrees well with the coincident temperature measured by the bow thermistor at $5.5 \mathrm{~m}$ $\left(<0.02{ }^{\circ} \mathrm{C}\right.$ difference) (Fig. 6c). There is no evidence that the ship's thrusters/propellers disrupted the near-surface gradients.

We compare the NSOP temperature profile with thermistor readings from a series of Sea-Bird Scientific (SBE 56) sensors $(0.3,0.6,1.5,3.5$ and $7 \mathrm{~m}$ depth) mounted on a nearby temperature chain moored $\sim 2.8 \mathrm{~km}$ away $\left(49.403^{\circ} \mathrm{N},-8.606^{\circ} \mathrm{E}\right)$ from the deployment site . The vertical profile implied by the NSOP deployment agrees with the mooring data (Fig. 6c), and corroborates the warming of the upper few metres of the ocean observed during the deployment. The agreement between these independent datasets suggests that it is unlikely that NSOP caused any significant localized warming of surface waters. The mean difference between NSOP temperature from discrete depths and the mooring sensors is $0.02^{\circ} \mathrm{C}$. The surface data from the NSOP upcast show less agreement with the mooring, with NSOP temperatures $\sim 0.05^{\circ} \mathrm{C}$ lower than the $0.3 \mathrm{~m}$ and $0.6 \mathrm{~m}$ mooring sensors. During the profile the ship drifted $\sim 1 \mathrm{~km}$ from the start position of the profile and a further $0.2 \mathrm{~km}$ from the mooring. The small offset between the NSOP surface temperatures and the mooring may be driven by horizontal variability between the deployment and mooring locations. It is also possible that turbulence mixed warm surface waters down into cooler sub-surface layers. Turbulence could have been generated around the NSOP sampling frame or by an increase in wave-driven mixing when the significant wave height increased at $\sim$ 15:00 UTC (Fig. S4a).

Seawater density (Fig. 7a) was calculated using the salinity and temperature profile data (Fig. 6a, b) and the 1983 Unesco equation of state (Millero and Poisson, 1981). As expected, with little variation in the salinity, changes in the density profile are dominated by temperature. The down- and upcasts for $\mathrm{CO}_{2}$ show excellent agreement below $2.5 \mathrm{~m}$. Surface water $(<2 \mathrm{~m}) \mathrm{CO}_{2}$ is $2-4 \mu \mathrm{atm}$ higher than at $5 \mathrm{~m}$ (Fig. $7 \mathrm{~b}$ ). Elevated surface $\mathrm{CO}_{2}$ could be explained by a sustained flux from the atmosphere into a near-surface stratified layer with inhibited deepwater exchange. Under this assumption a vertical gradient in seawater $\mathrm{CO}_{2}$ would need to be established shortly after the temperature gradient. A paired $t$ test showed that the $f \mathrm{CO}_{2}$ measured in the surface bins on the downcast and upcast are were significantly different $(p=<0.001)$. The deepening of the surface stratified layer could explain the more homogeneous $\mathrm{CO}_{2}$ during the upcast. It is worth noting that in addition to physical processes, plankton trapped within the surface layer could also modify the surface $\mathrm{CO}_{2}$. Trace gas concentrations may also be different in the sea surface microlayer but sampling that close to the surface is 

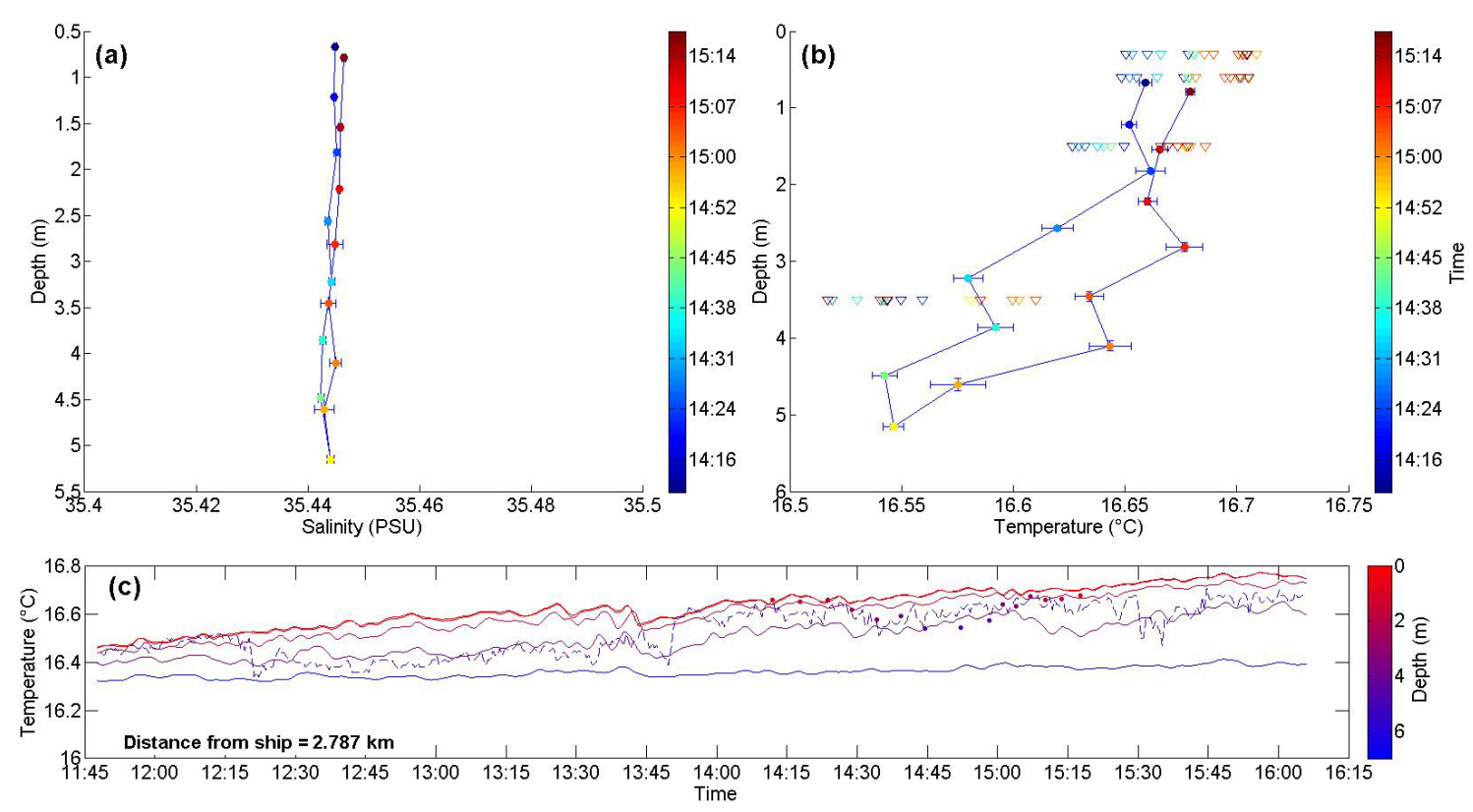

Figure 6. Salinity and temperature in the central Celtic Sea on 30 July 2015. NSOP profiles of salinity (a) and temperature (b) were derived using depth bins as described in Sect. 2.6. Data points are coloured by sampling time. Vertical and horizontal error bars show 2 standard errors of the mean in each depth bin. Coloured triangles in (b) are time-averaged temperature for four depths $(0.3,0.6,1.5$ and $3.5 \mathrm{~m})$ at the nearby central Celtic Sea temperature mooring $\left(49.403^{\circ} \mathrm{N},-8.606^{\circ} \mathrm{E}\right)$. (c) Time series of temperature at the mooring. Time series of temperature at depths $(0.3,0.6,1.5$ and $3.5 \mathrm{~m})$ are solid lines whereas the dashed line is the underway temperature at $5.5 \mathrm{~m}$ from RRS Discovery (located $2.8 \mathrm{~km}$ from the mooring). The mooring and underway temperatures are coloured according to their sample depth, where red is the air-sea interface. The circles are binned temperature data from NSOP, which have also been coloured to reflect the depth of collection.

beyond the capabilities of NSOP. Complementary measurements of the sea surface microlayer could be made using other state-of-the-art purpose-built sampling platforms such as the Sea Surface Scanner (Ribas-Ribas et al., 2017).

To assess measurement accuracy the NSOP Liqui-Cel $\mathrm{CO}_{2}$ system was compared against an independent $\mathrm{CO}_{2}$ system that had a showerhead equilibrator coupled to the ship's seawater supply pumped from $5.5 \mathrm{~m}$ below the sea surface (Hardman-Mountford et al., 2008; Kitidis et al., 2012). Technical issues meant that the underway $\mathrm{CO}_{2}$ system installed on the RRS Discovery was not functioning during the deployment detailed above. However, during a deployment on 19 July 2015 , the $f \mathrm{CO}_{2(\mathrm{sw})}$ measured by NSOP at $5 \mathrm{~m}$ agreed well with independent measurements from the underway system, with difference of $1.7 \pm 4.18 \mu \mathrm{atm}$. The agreement between the two systems is in line with previous intercomparisons (Ribas-Ribas et al., 2014; Körtzinger et al., 2000).

\subsection{Coastal deployment}

DMS profiles were collected on a small research vessel on 15 April 2014. The NSOP was deployed within the Plymouth Sound at 12:00 UTC and recovered 95 min later (Fig. 8). In the sheltered environment behind the breakwater the standard deviation in depth was $\pm 0.10 \mathrm{~m}$, smaller than observed during open ocean profiles. Seawater temperature and salinity demonstrate clear structure, with lower temperatures and higher salinities associated with sub-surface water. Two river estuaries (Plym and Tamar) converge and flow out to the open ocean through the Plymouth Sound. We likely observed a freshwater surface lens that was protected from wave-driven mixing and had been warmed over the course of the day. We used a different miniCTD during this deployment and were thus also able to collect fluorescence data (Fig. 8d).

Temperature profiles (Fig. 9a) show a sharp discontinuity in the downcast at $\sim 5 \mathrm{~m}$ whereas in the upcast the thermocline had shoaled to $\sim 3.5 \mathrm{~m}$. The salinity profiles suggest similar mixing depths to the temperature profiles, with lower salinity water at the surface (Fig. 9b). The increase in fluorescence with depth (Fig. 9c) is either due to reductions in chlorophyll concentration close to the sea surface or because of quenching of the phytoplankton photosynthetic apparatus, which is often observed in surface waters that experience strong irradiance (Sackmann et al., 2008; Biermann et al., 2015). DMS concentrations reduce steadily with depth (Fig. 9d), which is likely explained by changes in DMS production and consumption rates by the biological community (Galí et al., 2013). The DMS profiles from the upcast and the downcast are very similar, with the largest difference at the very surface. A large difference in the surface-most data point can also be seen in the temperature data, and may re- 

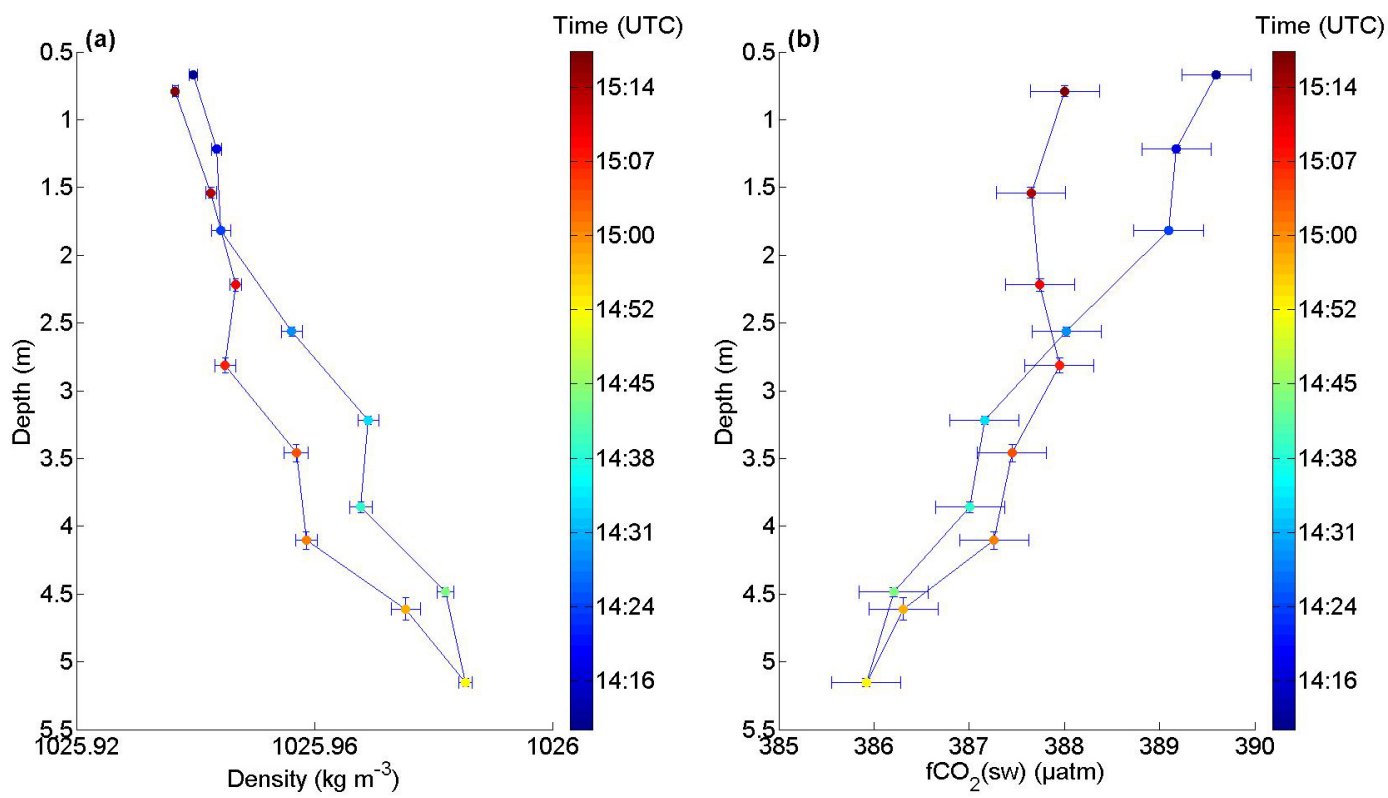

Figure 7. NSOP density (a) and $f \mathrm{CO}_{2(\mathrm{sw})}$, (b) profiles from the Celtic Sea on 30 July 2015. Data points are coloured by sample time. Vertical error bars correspond to 2 standard errors of the mean in each depth bin. The horizontal error bars in (a) are 2 standard errors of the mean, whereas in (b) they are the propagated error from the binned measurements used to calculate $f \mathrm{CO}_{2(\mathrm{sw})}$.

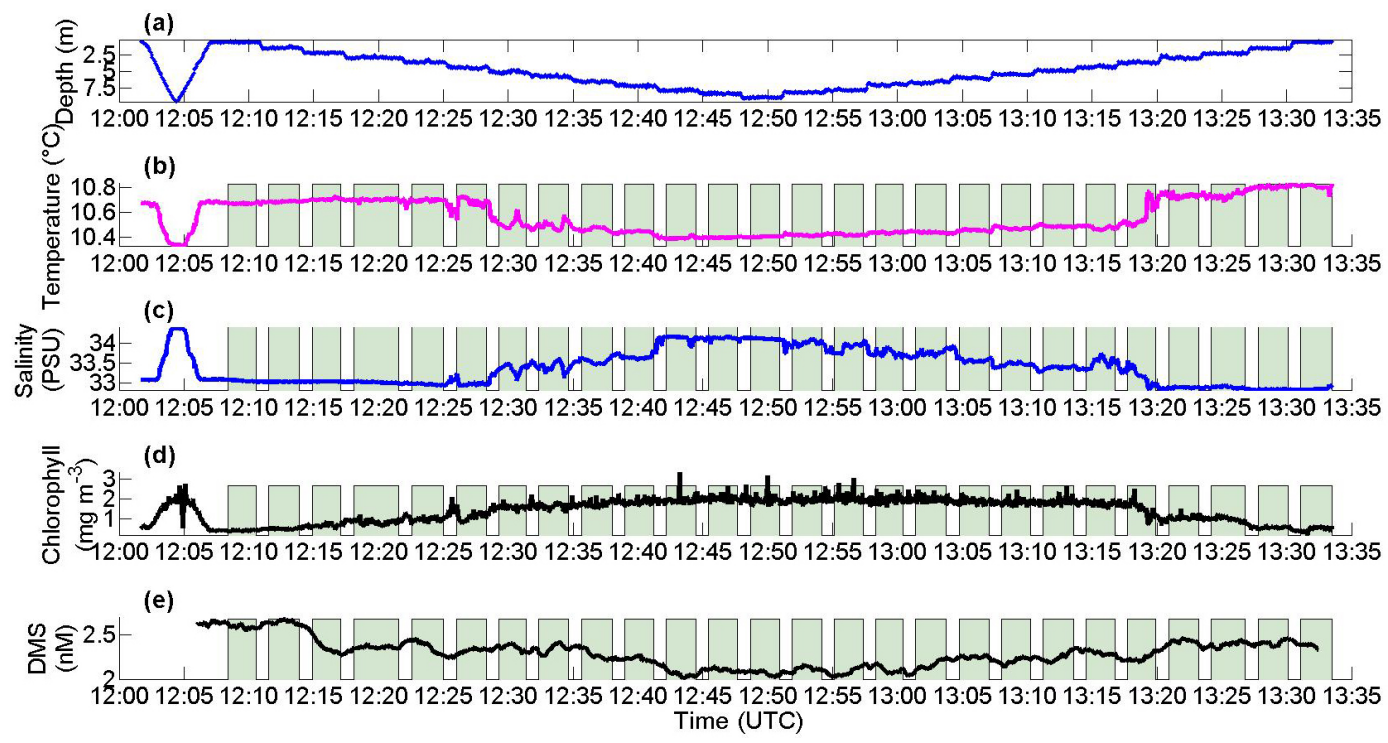

Figure 8. Time series measurements during an NSOP deployment in Plymouth Sound on 15 April 2014: depth (a), temperature (b), salinity (c), chlorophyll fluorescence (d) and $\operatorname{DMS}_{(\mathrm{sw})}$ (e). Data used for depth bin analysis (Sect. 2.6) are identified by a shaded background. The beginning of the time series is an example of a continuous profile (see Sect. 2.2).

flect mixing with sub-surface waters due to the motion of NSOP or short timescale variations in the physical environment.

\section{Summary}

This paper describes a near-surface ocean profiler (NSOP) designed to measure vertical trace gas profiles near the airsea interface. NSOP is unique in approach as its sampling frame is lowered from a buoy that rides the ocean swell, reducing relative motion of the frame and hence fluctuations in sampling depth. The NSOP design facilitates near-surface 

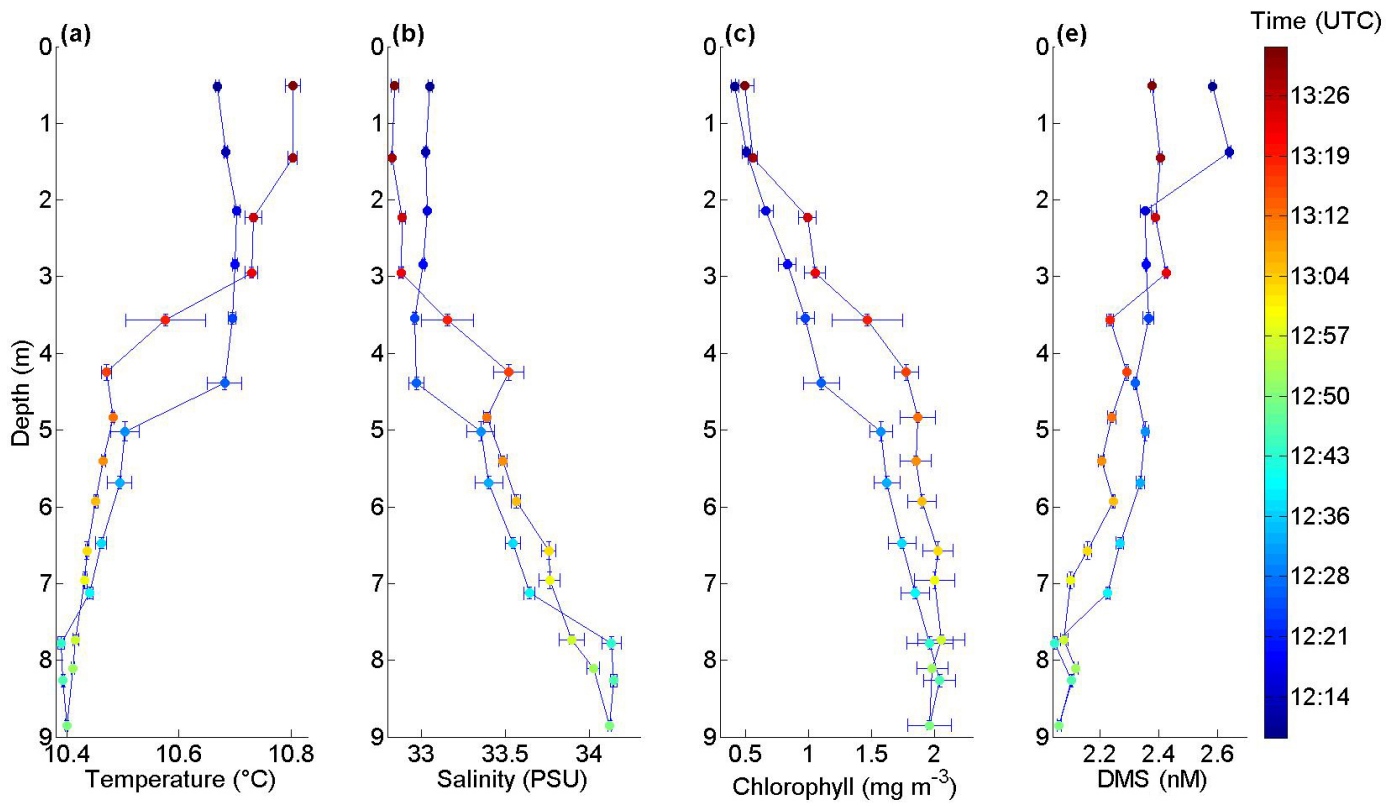

Figure 9. NSOP profiles collected in Plymouth Sound on 15 April 2014: temperature (a), salinity (b), chlorophyll fluorescence (c) and $\mathrm{DMS}_{(\mathrm{sw})}$ (d). Data are coloured by sample time. Vertical and horizontal error bars are 2 standard errors of the mean (SEM) in each depth bin.

$(<0.5 \mathrm{~m})$ sampling, significantly improving the capability to resolve vertical gradients. Other benefits include the ability to sample away from ship-driven turbulence and the flexibility to make a large range of near-surface measurements. The NSOP sampling frame houses the miniCTD and also has the capacity to incorporate additional sensors (e.g. turbulence, dissolved oxygen and other measures of phytoplankton abundance and photosynthetic health). The ability to collect water from discrete depths facilitates the collection of nearsurface samples that require additional processing or take longer to analyse (e.g. TA, dissolved inorganic carbon, nutrients, the DMS-precursor DMSP, dissolved organic carbon). The NSOP is highly versatile and can be used for continuous or discrete profiling. Further development could adjust winch payout speed and enable continuous, high-resolution depth profiles for slower response time measurements (e.g. $f \mathrm{CO}_{2(\mathrm{sw})}$ ).

Near-surface stratification in the upper few metres of the ocean due to temperature and salinity gradients is a welldocumented phenomenon. The presence or absence of chemical and biological gradients within near-surface stratified layers has been difficult to assess. NSOP is a platform with the capability to successfully resolve gradients in these nearsurface layers. The data presented in this paper demonstrate that near-surface gradients in trace gases can lead to substantially different fluxes depending upon the seawater depth that is used to calculate the flux. Assuming that the effect of temperature and salinity gradients on the flux can be accounted for using remote sensing methods (e.g Shutler et al., 2016), then the change in flux is directly proportional to the change in $\Delta \mathrm{C}$. In the case of the coastal DMS profile, a higher concentration $(2.58 \pm 0.02 \mathrm{nM})$ was observed $0.5 \mathrm{~m}$ below the sea surface compared to concentrations at $5 \mathrm{~m}(2.36 \pm 0.03 \mathrm{nM})$. Assuming that the atmospheric concentration of DMS was negligible (a typical approach for DMS fluxes (see Lana et al., 2011), computing the flux with the $5 \mathrm{~m}$ waterside concentration instead of the $0.5 \mathrm{~m}$ waterside concentration means the flux is underestimated by $9.3 \%$. In the case of the Celtic Sea $\mathrm{CO}_{2}$ profile, the concentration at $0.5 \mathrm{~m}(389.60 \pm 0.36 \mu \mathrm{atm})$ was higher than at $5 \mathrm{~m}(385.92 \pm 0.36 \mu \mathrm{atm})$. The atmospheric $\mathrm{CO}_{2}$ concentration was $398.1 \pm 0.3 \mu \mathrm{atm}$, which means that the surface water was less undersaturated than implied by the seawater concentration at $5 \mathrm{~m}$. Using the $5 \mathrm{~m}$ waterside $\mathrm{CO}_{2}$ concentration leads to an overestimation of the $\Delta \mathrm{C}$ and flux by $43.5 \% \mathrm{com}$ pared to using the $0.5 \mathrm{~m}$ waterside $\mathrm{CO}_{2}$ concentration. The magnitudes of these concentration gradients are significant. However, such gradients (in magnitude and direction) do not persist for all hours of the day, under different environmental conditions and in all regions of the global ocean. A subsequent publication will discuss NSOP data collected during four cruises as well as the wider prevalence and implications of near-surface $\mathrm{CO}_{2}$ gradients.

Data availability. Relevant data for this paper can be found in the excel spreadsheet in the Supplement. 


\section{The Supplement related to this article is available online at https://doi.org/10.5194/os-13-649-2017-supplement.}

Competing interests. The authors declare that they have no conflict of interest.

Acknowledgements. We thank the captains and crews of the RV Plymouth Quest and RRS Discovery for their assistance with deploying NSOP, Christopher Balfour and Dave Sivyer for maintenance of the central Celtic Sea mooring near-surface temperature sensors, Vassilis Kitidis for supplying underway $\mathrm{CO}_{2}$ data and Burke Hales for advice concerning Liqui-Cel $\mathrm{CO}_{2}$ measurements. This research was made possible by PML internal funding, a NERC funded studentship (NE/L000075/1), temperature sensors on the central Celtic Sea mooring (NE/K002058/1) and the NERC Shelf Sea Biogeochemistry pelagic research programme (NE/K002007/1). The RRS Discovery underway data were supplied by the Natural Environment Research Council.

Edited by: Piers Chapman

Reviewed by: Mariana Ribas-Ribas and two anonymous referees

\section{References}

Bakker, D. C. E., Pfeil, B., Landa, C. S., Metzl, N., O’Brien, K. M., Olsen, A., Smith, K., Cosca, C., Harasawa, S., Jones, S. D., Nakaoka, S.-I., Nojiri, Y., Schuster, U., Steinhoff, T., Sweeney, C., Takahashi, T., Tilbrook, B., Wada, C., Wanninkhof, R., Alin, S. R., Balestrini, C. F., Barbero, L., Bates, N. R., Bianchi, A. A., Bonou, F., Boutin, J., Bozec, Y., Burger, E. F., Cai, W.-J., Castle, R. D., Chen, L., Chierici, M., Currie, K., Evans, W., Featherstone, C., Feely, R. A., Fransson, A., Goyet, C., Greenwood, N., Gregor, L., Hankin, S., Hardman-Mountford, N. J., Harlay, J., Hauck, J., Hoppema, M., Humphreys, M. P., Hunt, C. W., Huss, B., Ibánhez, J. S. P., Johannessen, T., Keeling, R., Kitidis, V., Körtzinger, A., Kozyr, A., Krasakopoulou, E., Kuwata, A., Landschützer, P., Lauvset, S. K., Lefèvre, N., Lo Monaco, C., Manke, A., Mathis, J. T., Merlivat, L., Millero, F. J., Monteiro, P. M. S., Munro, D. R., Murata, A., Newberger, T., Omar, A. M., Ono, T., Paterson, K., Pearce, D., Pierrot, D., Robbins, L. L., Saito, S., Salisbury, J., Schlitzer, R., Schneider, B., Schweitzer, R., Sieger, R., Skjelvan, I., Sullivan, K. F., Sutherland, S. C., Sutton, A. J., Tadokoro, K., Telszewski, M., Tuma, M., van Heuven, S. M. A. C., Vandemark, D., Ward, B., Watson, A. J., and Xu, S.: A multidecade record of high-quality $f \mathrm{CO}_{2}$ data in version 3 of the Surface Ocean $\mathrm{CO}_{2}$ Atlas (SOCAT), Earth Syst. Sci. Data, 8, 383413, https://doi.org/10.5194/essd-8-383-2016, 2016.

Bange, H. W., Bell, T. G., Cornejo, M., Freing, A., Uher, G., UpstillGoddard, R. C., and Zhang, G.: MEMENTO: a proposal to develop a database of marine nitrous oxide and methane measurements, Environ. Chem., 6, 195-197, 2009.

Bell, T. G., De Bruyn, W., Miller, S. D., Ward, B., Christensen, K. H., and Saltzman, E. S.: Air-sea dimethylsulfide (DMS) gas transfer in the North Atlantic: evidence for limited interfacial gas exchange at high wind speed, Atmos. Chem. Phys., 13, 1107311087, https://doi.org/10.5194/acp-13-11073-2013, 2013.

Bell, T. G., De Bruyn, W., Marandino, C. A., Miller, S. D., Law, C. S., Smith, M. J., and Saltzman, E. S.: Dimethylsulfide gas transfer coefficients from algal blooms in the Southern Ocean, Atmos. Chem. Phys., 15, 1783-1794, https://doi.org/10.5194/acp15-1783-2015, 2015.

Dickson, A. G., Sabine, C. L., and Christian, J. R.: Guide to best practices for ocean $\mathrm{CO}_{2}$ measurements, Measurements, PICES Special Publication, 3, 91-102, 2007.

Donlon, C., Minnett, P., Gentemann, C., Nightingale, T., Barton, I., Ward, B., and Murray, M.: Toward improved validation of satellite sea surface skin temperature measurements for climate research, J. Clim., 15, 353-369, 2002.

Durham, W. M., Kessler, J. O., and Stocker, R.: Disruption of vertical motility by shear triggers formation of thin phytoplankton layers, Science, 323, 1067-1070, 2009.

Fairall, C., Bradley, E. F., Godfrey, J., Wick, G., Edson, J. B., and Young, G.: Cool-skin and warm-layer effects on sea surface temperature, J. Geophys. Res., 101, 1295-1308, 1996.

Frankignoulle, M. and Borges, A. V.: European continental shelf as a significant sink for atmospheric carbon dioxide, Global Biogeochem. Cy., 15, 569-576, 2001.

Galí, M., Simó, R., Vila-Costa, M., Ruiz-González, C., Gasol, J. M., and Matrai, P.: Diel patterns of oceanic dimethylsulfide (DMS) cycling: Microbial and physical drivers, Global Biogeochem. Cy., 27, 620-636, 2013.

Hales, B., Chipman, D., and Takahashi, T.: High-frequency measurement of partial pressure and total concentration of carbon dioxide in seawater using microporous hydrophobic membrane contractors, Limnol. Oceanogr.-Meth., 2, 356-364, 2004.

Hardman-Mountford, N. J., Moore, G., Bakker, D. C., Watson, A. J., Schuster, U., Barciela, R., Hines, A., Moncoiffé, G., Brown, J., and Dye, S.: An operational monitoring system to provide indicators of $\mathrm{CO}_{2}$-related variables in the ocean, ICES J. Mar. Sci., 65, 1498-1503, 2008.

Kitidis, V., Hardman-Mountford, N. J., Litt, E., Brown, I., Cummings, D., Hartman, S., Hydes, D., Fishwick, J. R., Harris, C., and Martinez-Vicente, V.: Seasonal dynamics of the carbonate system in the Western English Channel, Cont. Shelf Res., 42, 30-40, 2012.

Körtzinger, A., Mintrop, L., Wallace, D. W., Johnson, K. M., Neill, C., Tilbrook, B., Towler, P., Inoue, H. Y., Ishii, M., and Shaffer, G.: The international at-sea intercomparison of $\mathrm{fCO}_{2}$ systems during the R/V Meteor Cruise 36/1 in the North Atlantic Ocean, Mar. Chem., 72, 171-192, 2000.

Lana, A., Bell, T., Simó, R., Vallina, S. M., Ballabrera-Poy, J., Kettle, A., Dachs, J., Bopp, L., Saltzman, E., and Stefels, J.: An updated climatology of surface dimethlysulfide concentrations and emission fluxes in the global ocean, Global Biogeochem. Cy., 25, GB1004, https://doi.org/10.1029/2010GB003850, 2011.

Le Quéré, C., Andrew, R. M., Canadell, J. G., Sitch, S., Korsbakken, J. I., Peters, G. P., Manning, A. C., Boden, T. A., Tans, P. P., Houghton, R. A., Keeling, R. F., Alin, S., Andrews, O. D., Anthoni, P., Barbero, L., Bopp, L., Chevallier, F., Chini, L. P., Ciais, P., Currie, K., Delire, C., Doney, S. C., Friedlingstein, P., Gkritzalis, T., Harris, I., Hauck, J., Haverd, V., Hoppema, M., Klein Goldewijk, K., Jain, A. K., Kato, E., Körtzinger, A., Landschützer, P., Lefèvre, N., Lenton, A., Lienert, S., Lombardozzi, 
D., Melton, J. R., Metzl, N., Millero, F., Monteiro, P. M. S., Munro, D. R., Nabel, J. E. M. S., Nakaoka, S.-I., O’Brien, K., Olsen, A., Omar, A. M., Ono, T., Pierrot, D., Poulter, B., Rödenbeck, C., Salisbury, J., Schuster, U., Schwinger, J., Séférian, R., Skjelvan, I., Stocker, B. D., Sutton, A. J., Takahashi, T., Tian, H., Tilbrook, B., van der Laan-Luijkx, I. T., van der Werf, G. R., Viovy, N., Walker, A. P., Wiltshire, A. J., and Zaehle, S.: Global Carbon Budget 2016, Earth Syst. Sci. Data, 8, 605-649, https://doi.org/10.5194/essd-8-605-2016, 2016.

Liss, P. S. and Slater, P. G.: Flux of Gases across the Air-Sea Interface, Nature, 247, 181-184, 1974.

Loose, B., Stute, M., Alexander, P., and Smethie, W.: Design and deployment of a portable membrane equilibrator for sampling aqueous dissolved gases, Water Resour. Res., 45, 2009.

Marandino, C. A., De Bruyn, W. J., Miller, S. D., and Saltzman, E. S.: Open ocean DMS air/sea fluxes over the eastern South Pacific Ocean, Atmos. Chem. Phys., 9, 345-356, https://doi.org/10.5194/acp-9-345-2009, 2009.

McNeil, C. L. and Merlivat, L.: The warm oceanic surface layer: Implications for $\mathrm{CO}_{2}$ fluxes and surface gas measurements, Geophys. Res. Lett., 23, 3575-3578, 1996.

Miller, S. D., Marandino, C., and Saltzman, E. S.: Ship-based measurement of air-sea $\mathrm{CO}_{2}$ exchange by eddy covariance, J. Geophys. Res.-Atmos., 115, 2010.

Millero, F. J. and Poisson, A.: International one-atmosphere equation of state of seawater, Deep-Sea Res. Pt. A, 28, 625-629, 1981.

Quinn, P. and Bates, T.: The case against climate regulation via oceanic phytoplankton sulphur emissions, Nature, 480, 51-56, 2011.

Ribas-Ribas, M., Rerolle, V., Bakker, D. C., Kitidis, V., Lee, G., Brown, I., Achterberg, E. P., Hardman-Mountford, N., and Tyrrell, T.: Intercomparison of carbonate chemistry measurements on a cruise in northwestern European shelf seas, Biogeosciences, 11, 4339-4355, https://doi.org/10.5194/bg-11-43392014, 2014.

Ribas-Ribas, M., Mustaffa, N. I. H., Rahlff, J., Stolle, C., and Wurl, O.: Sea Surface Scanner (S3): A Catamaran for High-resolution Measurements of Biogeochemical Properties of the Sea Surface Microlayer, J. Atmos. Ocean. Technol., 1433-1448, 2017.

Robertson, J. E. and Watson, A. J.: Thermal skin effect of the surface ocean and its implications for $\mathrm{CO}_{2}$ uptake, Nature, 358, 738-740, 1992.

Royer, S.-J., Galí, M., Saltzman, E. S., McCormick, C. A., Bell, T. G., and Simó, R.: Development and validation of a shipboard system for measuring high-resolution vertical profiles of aqueous dimethylsulfide concentrations using chemical ionisation mass spectrometry, Environ. Chem., 11, 309-317, 2014.

Royer, S. J., Galí, M., Mahajan, A. S., Ross, O. N., Pérez, G. L., Saltzman, E. S., and Simó, R.: A high-resolution time-depth view of dimethylsulphide cycling in the surface sea, Sci. Rep., 6, 32325, https://doi.org/10.1038/srep32325, 2016.

Sackmann, B. S., Perry, M. J., and Eriksen, C. C.: Seaglider observations of variability in daytime fluorescence quenching of chlorophyll- $a$ in Northeastern Pacific coastal waters, Biogeosciences Discuss., 5, 2839-2865, https://doi.org/10.5194/bgd-52839-2008, 2008.

Saltzman, E. S., De Bruyn, W. J., Lawler, M. J., Marandino, C. A., and McCormick, C. A.: A chemical ionization mass spectrometer for continuous underway shipboard analysis of dimethylsulfide in near-surface seawater, Ocean Sci., 5, 537-546, https://doi.org/10.5194/os-5-537-2009, 2009.

Shutler, J. D., Land, P. E., Piolle, J.-F., Woolf, D. K., GoddijnMurphy, L., Paul, F., Girard-Ardhuin, F., Chapron, B., and Donlon, C. J.: FluxEngine: A Flexible Processing System for Calculating Atmosphere-Ocean Carbon Dioxide Gas Fluxes and Climatologies, J. Atmos. Ocean. Technol., 33, 741-756, 2016.

Smyth, T. J., Fishwick, J. R., Lisa, A.-M., Cummings, D. G., Harris, C., Kitidis, V., Rees, A., Martinez-Vicente, V., and Woodward, E. M.: A broad spatio-temporal view of the Western English Channel observatory, J. Plankt. Res., 32, 585-601, 2010.

Takahashi, T., Olafsson, J., Goddard, J. G., Chipman, D. W., and Sutherland, S.: Seasonal variation of $\mathrm{CO}_{2}$ and nutrients in the high-latitude surface oceans: A comparative study, Global Biogeochem. Cy., 7, 843-878, 1993.

Turk, D., Zappa, C. J., Meinen, C. S., Christian, J. R., Ho, D. T., Dickson, A. G., and McGillis, W. R.: Rain impacts on $\mathrm{CO}_{2}$ exchange in the western equatorial Pacific Ocean, Geophys. Res., Lett., 37, 2010.

Walker, C. F., Harvey, M. J., Smith, M. J., Bell, T. G., Saltzman, E. S., Marriner, A. S., McGregor, J. A., and Law, C. S.: Assessing the potential for dimethylsulfide enrichment at the sea surface and its influence on air-sea flux, Ocean Sci., 12, 1033-1048, https://doi.org/10.5194/os-12-1033-2016, 2016.

Wanninkhof, R.: Relationship between wind speed and gas exchange over the ocean revisited, Limnol. Oceanogr.-Meth., 12, 351-362, 2014.

Ward, B., Wanninkhof, R., McGillis, W. R., Jessup, A. T., DeGrandpre, M. D., Hare, J. E., and Edson, J. B.: Biases in the air-sea flux of $\mathrm{CO}_{2}$ resulting from ocean surface temperature gradients, J. Geophys. Res.-Ocean. (1978-2012), 109, 2004.

Webb, J. R., Maher, D. T., and Santos, I. R.: Automated, in situ measurements of dissolved $\mathrm{CO}_{2}, \mathrm{CH}_{4}$, and $\delta 13 \mathrm{C}$ values using cavity enhanced laser absorption spectrometry: Comparing response times of air-water equilibrators, Limnol. Oceanogr-Meth., 14, 323-337, 2016.

Woolf, D., Land, P. E., Shutler, J. D., Goddijn-Murphy, L., and Donlon, C. J.: On the calculation of air-sea fluxes of $\mathrm{CO}_{2}$ in the presence of temperature and salinity gradients, J. Geophys. Res.Ocean., 121, 1229-1248, 2016.

Yang, M., Beale, R., Smyth, T., and Blomquist, B.: Measurements of OVOC fluxes by eddy covariance using a proton-transfer-reaction mass spectrometer - method development at a coastal site, Atmos. Chem. Phys., 13, 6165-6184, https://doi.org/10.5194/acp-13-6165-2013, 2013.

Ziska, F., Quack, B., Abrahamsson, K., Archer, S. D., Atlas, E., Bell, T., Butler, J. H., Carpenter, L. J., Jones, C. E., Harris, N. R. P., Hepach, H., Heumann, K. G., Hughes, C., Kuss, J., Krüger, K., Liss, P., Moore, R. M., Orlikowska, A., Raimund, S., Reeves, C. E., Reifenhäuser, W., Robinson, A. D., Schall, C., Tanhua, T., Tegtmeier, S., Turner, S., Wang, L., Wallace, D., Williams, J., Yamamoto, H., Yvon-Lewis, S., and Yokouchi, Y.: Global sea-to-air flux climatology for bromoform, dibromomethane and methyl iodide, Atmos. Chem. Phys., 13, 89158934, https://doi.org/10.5194/acp-13-8915-2013, 2013. 